\title{
EFEKTIVITAS PROGRAM TEMPAT OLAH SAMPAH SETEMPAT (TOSS) DALAM PENGELOLAAN SAMPAH DI DESA GUNAKSA, KABUPATEN KLUNGKUNG
}

\author{
Oleh: \\ Komang Ema Marsitadewi, Lilik Antarini, I Wayan Sudemen \\ Universitas Warmadewa \\ Email: emarsitadewi@gmail.com \\ Universitas Warmadewa \\ Email: lilikantaryny@yahoo.com \\ Universitas Warmadewa \\ Email: iwayansudemen@yahoo.com
}

\begin{abstract}
A $\mathrm{K}$ abupaten Klungkung menjadi salah satu contoh wilayah yang mengembangkan pembangkit listrik alternatif melalui program Tempat Olah Sampah Setempat (TOSS). Program ini telah dijalankan 3 tahun dan pelaksanaannya, program TOSS ini mengalami banyak hambatan seperti kemampuan pengelolaan desa masing-masing, dana hingga keterbatasan pengadaan alat pengelolaan sampah. Metode yang digunakan dalam penelitian ini adalah metode kuantitatif. Data diperoleh dengan menyebarkan kuisioner kepada 98 orang dan dari laporan-laporan, artikel ilmiah atau penelitian sejenis yang berhubungan dengan Program TOS). Keefektifan TOSS dilihat dalam tiga bagian yakni: input, proses, dan output. Dari sisi input, hasil penelitian menunjukkan jenis sampah yang diperoleh melalui pemilahan sampah memperoleh rata-rata skor sebesar 2,28 hal ini menandakan bahwa masyarakat kurang baik dalam melakukan pemilahan sampah. Dari sisi proses, pengumpulan sampah oleh petugas sudah menunjukkan kategori baik. Hal ini didukung oleh tersedianya kendaraan pengangkut sampah ke tempat pengolahan. Sedangkan pengelolaan sampah yang dilakukan petugas menunjukkan bahwa seluruh pekerja TOSS menyatakan secara rutin dan terus menerus mengolah sampah yang masuk ke TOSS Desa Gunaksa. Dari sisi output, perubahan volume sampah yang dihasilkan masyarakat menunjukkan rata-rata skor 2,66 yang berarti berada dalam kategori baik. Dengan demikian maka dapat dikatakan perubahan volume sampah semakin berkurang dengan adanya TOSS di Desa Gunaksa ini.
\end{abstract}

Kata Kunci: Efektivitas, Pengelolaan Sampah, Tempat Olah Sampah Setempat, Kabupaten Klungkung.

$K$ lungkung Regency is an example of an area that is developing alternative power plants through the Local Waste Processing (TOSS) program. This program has been running for 3 years and in its implementation, the TOSS program has experienced many obstacles, such as the ability to manage each village, funds to the limited procurement of waste management tools. The method used in this research is quantitative method. Data obtained by distributing questionnaires to 98 people and from reports, scientific articles or similar research related to the TOS Program). The effectiveness of TOSS is seen in three parts: input, process, and output. From the input side, the results showed that the type of waste obtained through sorting the waste obtained an average score of 2.28 , this indicates that the community is not good at sorting waste. In terms of process, waste collection by officers has shown a good category. This is supported by the availability of vehicles to transport waste to the processing plant. Meanwhile, waste management carried out by officers shows that all TOSS workers state that they routinely and continuously process the waste that enters TOSS Gunaksa Village. From the output side, the change in the volume of waste produced by the community shows an average score of 2.66 which means that it is in the good category. Thus, it can be said that changes in the volume of waste are decreasing with the existence of TOSS in Gunaksa Village.

Keywords: Effectiveness, Solid Waste Management, Local Waste Processing Site, Klungkung Regency.

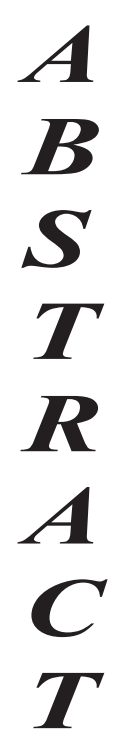




\section{A. PENDAHULUAN}

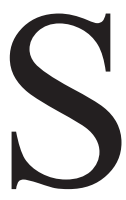
ampah merupakan masalah bagi pemerintah dan masyarakat, baik di perkotaan maupun di pedesaan. Sebenarnya sampah masih bisa dikelola dan dimanfaatkan untuk berbagai keperluan, diantaranya adalah untuk pupuk dalam upaya menyuburkan lahan pertanian dan sampah plastik bisa didaur ulang menjadi bahan kerajinan. Tetapi masih banyak masyarakat yang menganggap sampah sebagai sumber penyakit, juga mencemarkan lingkungan dengan bau busuk yang menyengat. Masyarakat pedesaan yang rata-rata jumlah lahan pertaniannya luas seharusnya bisa lebih memanfaatkan sampah untuk membantu proses pertaniannya, namun tidak banyak yang menyadari akan hal itu.

Berbagai upaya dilakukan untuk menangani sampah. Namun upaya tersebut kerap menimbulkan kendala. Sulitnya mencari lahan untuk tempat pembuangan sementara (TPS) membuat masyarakat membuang sampah ke pinggir jalan sehingga membuat pemandangan tidak elok, bahkan sering kali masyarakat membuangnya ke sungai dengan tanpa berfikir panjang bahwa itu akan mencemari sungai. Dengan membuang sampah seenaknya membuat wajah desa yang dikenal asri menjadi jelek dengan tumpukan sampah disana-sini. Seiring pertumbuhan penduduk, jumlah produksi sampah menjadi semakin meningkat. Salah satu yang menimbulkan masalah persampahan adalah tidak adanya fasilitas untuk masyarakat membuang sampah pada tempatnya, baik itu ditingkat Desa maupun maupun Kecamatan.

Pembuangan sampah yang berakhir baik itu di TPS ataupun di TPA bukan solusi akhir untuk mengelola sampah. Pembuangan sampah yang berakhir di TPS ataupun TPA malah membuka permasalahan baru yakni overload kapasitas dari TPS atau TPA itu sendiri. Hal ini pun terjadi di Kabupaten Klungkung. Kabupaten Klungkung, Bali menjadi salah satu contoh wilayah yang mengembangkan pembangkit listrik alternatif melalui program Tempat Olah Sampah Setempat (TOSS). Program ini merupakan hasil kerjasama antara Sekolah Tinggi Teknik (STT) Perusahaan Listrik Negara (PLN) dan PT Indonesia Power. Proses pengolahan TOSS melalui beberapa tahap hingga mampu menghasilkan listrik. Program ini telah dijalankan 3 tahun dan pelaksanaannya, program TOSS ini mengalami banyak hambatan seperti kemampuan pengelolaan desa masingmasing, dana hingga keterbatasan pengadaan alat pengelolaan sampah.

\section{B. METODE}

Metode yang digunakan ialah metode kuantitatif dengan menggunakan survey. Pengumpulan data dilakukan penyebaran kuesioner kepada 98 masyarakat yang berada di lingkungan tempat pengolahan TOSS dengan menggunakan metode Simple Random Sampling, dengan pertimbangan keterbatasan waktu dan biaya dari penulis. Penelitian ini menggunakan 
variable tunggal yaitu Program Tempat Olah Sampah Setempat (TOSS). Meskipun menggunakan variabel tunggal, akan dipaparkan indikator-indikator dan variabel tunggal tersebut. Untuk lebih jelasnya, berikut merupakan variabel dan indikator yang dimaksud:

\begin{tabular}{|c|c|}
\hline & Indikator \\
\hline \multirow[t]{3}{*}{$\begin{array}{l}\text { Program Tempat Olah } \\
\text { Sampah } \quad \text { Setempat } \\
\text { (TOSS) }\end{array}$} & $\begin{array}{l}\text { 1. Input } \\
\text { a. Jenis Sampah } \\
\text { b. Sumber Daya Manusia }\end{array}$ \\
\hline & $\begin{array}{l}\text { 2. Proses } \\
\text { a. Pengumpulan } \\
\text { b. Pemilihan } \\
\text { c. Pengolahan } \\
\text { d. Penjualan }\end{array}$ \\
\hline & $\begin{array}{l}\text { 3. Output } \\
\text { a. Perubahan volume sampah } \\
\text { b. Nilai ekonomis }\end{array}$ \\
\hline
\end{tabular}

\section{C.HASIL DAN PEMBAHASAN}

\section{a. Input (Jenis Sampah, Sumber daya manusia)}

Input merupakan bahan dalam melakukan program TOSS. Disini bahan yang dimaksud dibagi menjadi dua yakni jenis sampah dan sumber daya manusia yakni pegawai yang mengelola TOSS.

\section{a). Jenis Sampah}

Tabel 5.1

Pernyataan Responden terhadap Pembagian Sampah berdasarkan jenisnya

\begin{tabular}{|c|c|c|c|}
\hline No & Pernyataan & Jumlah (orang) & Skor \\
\hline 1 & Tidak pernah & 25 & 25 \\
\hline 2 & Jarang & 28 & 54 \\
\hline 3 & Kadang-Kadang & 31 & 93 \\
\hline 4 & Sering dan rutin & 10 & 40 \\
\hline \multirow{2}{*}{} & Jumlah & 93 & 212 \\
\cline { 2 - 4 } & Rata-rata skor & \multicolumn{2}{|c|}{$\mathbf{2 . 2 8}$} \\
\cline { 2 - 4 }
\end{tabular}

Sumber : Tabulasi Skor Hasil Jawaban Responden

Berdasarkan tabel 5.1 bahwa dari 93 responden dalam penelitian ini, 25 orang menyatakan tidak pernah memilah sampah berdasarkan jenisnya, 28 orang menyatakan jarang, 31 menyatakan kadang-kadang dan 10 menyatakan sering dan rutin memilah sampah berdasarkan jenisnya. Apabila dilihat dari rata-rata skor, pada pernyataan responden terkait jenis sampah memiliki skor sebesar 2,28 yang artinya kurang baik. Hal ini menandakan bahwa masyarakat kurang baik dalam melakukan pembagian sampah berdasarkan jenisnya yakni organik dan anorganik. 
Hasil kurang baik dari pembagian jenis sampah oleh masyarakat yang telah diperoleh diatas didasarkan dari beberapa alasan seperti tidak tahu jenis pilahan sampah, malas untuk memilah sampah, bahkan sampai tidak adanya tempat memilah sampah. Pada penelitian ini berikut alasan masyarakat tidak melakukan pemilahan sampah.

Tabel 5.2

Pernyataan Responden terhadap Alasan Tidak Melakukan Pemilahan

\begin{tabular}{|c|c|c|c|}
\hline No & Pernyataan & $\begin{array}{c}\text { Jumlah } \\
\text { (orang) }\end{array}$ & Skor \\
\hline 1 & Ribet memilah & 28 & 28 \\
\hline 2 & Tidak ada tempat memilah & 34 & 68 \\
\hline 3 & Malas & 14 & 42 \\
\hline 4 & Tidak Tahu & 14 & 56 \\
\hline \multirow{2}{*}{} & Jumlah & 90 & 194 \\
\cline { 2 - 4 } & Rata-rata skor & \multicolumn{2}{|c|}{$\mathbf{2 . 1 6}$} \\
\cline { 2 - 4 }
\end{tabular}

Sumber : Tabulasi Skor Hasil Jawaban Responden

Pada tabel diatas dapat dilihat bahwa jawaban terbanyak terhadap alasan tidak melakukan pemilahan yakni tidak adanya tempat memilah yakni sebanyak 34 jawaban responden. Kemudian diikuti oleh ribet memilah sebanyak 28 orang. Sedangakan untuk malas dan tidak tahu sama sama mendapatkan 14 jawaban. Jawaban ini menandakan bahwa masyarakat bukan tidak mengetahui jenis sampah ataupun tidak mengetahui bahwa sampah harus dipilah terlebih dahulu sebelum kemudian diambil oleh petugas TOSS.

Jawaban masyarakat terkait dengan alasan tidak melakukan pemilahan diatas apabila dikaitkan dengan teori, pemilahan sampah tidak memerlukan tempat atau lahan yang banyak.

\section{b). Sumber Daya Manusia}

Sumber daya manusia yang dimaksud pada penelitian ini ialah para pekerja TOSS Desa Gunaksa. Seluruh pekerja TOSS menyatakan bahwa jumlah pekerja TOSS sudah mencukupi dengan jumlah sampah yang harus diolah di TOSS Desa Gunaksa. Seluruh pekerja TOSS bekerja $\geq$ 4 jam setiap harinya.

b. Proses (Pengumpulan, Pemilihan, Pengelolaan, Penjualan)

Proses dalam pengelolaan TOSS dibagi menjadi empat tahapan. Dimulai dari pengumpulan sampah dari masyarakat, pemilahan sampah oleh pekerja TOSS, pengelolaan dan yang terakhir yakni penjualan. Hasil olahan data dari masing-masing tahapan dijabarkan dengan lebih rinci pada tabel dibawah ini. 


\section{a). Pengumpulan.}

Pengumpulan merupakan tahap awal dari proses pengelolaan TOSS Desa Gunaksa. Pada penelitian ini, pengumpulan difokuskan pada pengangkutan sampah dari masyarakat Desa Gunaksa. Berikut data yang diperoleh terkait pengangkutan sampah dari masyarakat oleh pekerja TOSS untuk dibawa ke TOSS Desa Gunaksa.

Tabel 5.3

Pernyataan Responden terhadap Pengangkutan Sampah dari sumber ke TOSS

\begin{tabular}{|c|c|c|c|}
\hline No & Pernyataan & Jumlah (orang) & Skor \\
\hline 1 & Tidak tepat waktu & 15 & 15 \\
\hline 2 & Jarang & 0 & 0 \\
\hline 3 & Kadang-kadang & 28 & 84 \\
\hline 4 & Tepat waktu & 50 & 200 \\
\hline \multirow{2}{*}{} & Jumlah & 95 & 299 \\
\cline { 2 - 4 } & Rata-rata skor & $\mathbf{3 . 2 2}$ \\
\cline { 2 - 4 }
\end{tabular}

Sumber : Tabulasi Skor Hasil Jawaban Responden

Tabel 5.3 menunjukkan hasil olahan data mengenai pengangkutan sampah dari sumber/masyarakat ke TOSS Desa Gunaksa. Pada tabel diatas menunjukkan bahwa 50 orang responden menjawab tepat waktu terhadap pengangkutan sampah dari masyarakat ke TOSS Desa Gunaksa. 28 orang responden menjawab kadang-kadang, 15 orang menjawab tidak tepat waktu. Sedangkan tidak ada satu orang responden pun yang menjawab jarang adanya pengangkutan sampah dari masyarakat ke TOSS.

Dari olahan data yang ada pada tabel 5.3, dapat diketahui bahwa rata-rata skor dari semua penilaian yakni 3,22, yang mana dalam interval tabulasi data menandakan baik. Hal ini dapat diartikan bahwa pengangkutan sampah dari masyarakat ke TOSS Desa Gunaksa sudah berjalan dengan baik.

Pengangkutan sampah dari masyarakat oleh pekerja TOSS Desa Gunaksa untuk dibawa ke tempat pengelolaan yang telah tergolong baik ini diperkuat dengan kendaraan pengangkut sampah yang tersedia telah mencukupi. Olahan data terkait kecukupan kendaraan pengangkut sampah dapat dilihat pada tabel dibawah ini.

Tabel 5.4

Pernyataan Responden terhadap Kecukupun Kendaraan

\begin{tabular}{|c|c|c|c|}
\hline No & Pernyataan & Jumlah (orang) & Skor \\
\hline 1 & Tidak mencukupi & 0 & 0 \\
\hline 2 & Belum mencukupi & 22 & 44 \\
\hline 3 & Mencukupi & 63 & 189 \\
\hline 4 & Sangat mencukupi & 7 & 28 \\
\hline \multirow{2}{*}{} & Jumlah & 92 & 261 \\
\cline { 2 - 4 } & Ratarataskor & \multicolumn{2}{c|}{$\mathbf{2 . 8 4}$} \\
\cline { 2 - 4 }
\end{tabular}

Sumber : Tabulasi Skor Hasil Jawaban Responden 
Pada tabel diatas menunjukkan bahwa mayoritas responden yakni sebanyak 63 orang menjawab mencukupi atas kendaraan pengangkut sampah di TOSS Desa Gunaksa. 22 orang menjawab belum mencukupi dan sisanya yakni sebanyak 7 orang menjawab sangat mencukupi. Rata rata skor atas pernyataan responden terhadap kecukupan kendaraan yakni 2,84. Nilai tersebut menandakan bahwa kendaraan pengangkut sampah berada pada dalam kategori baik atau juga dapat dikatakan mencukupi.

Hasil olahan data yang menunjukkan bahwa ketersediaan kendaraan pengangkutan sampah mencukupi mengatasi sampah TOSS Desa Gunaksa mendukung hasil penelitian bahwa proses pengangkutan sampah dari masyarakat untuk dibawa ke TOSS Desa Gunaksa berada pada kategori baik yakni tepat waktu dlam pengangkutan sampah.

\section{b). Pemilahan}

Pemilahan merupakan tahap kedua dalam proses pengelolaan TOSS setelah pengangkutan. Pemilahan dilakukan untuk mempermudah proses pengelolaan berikutnya yakni peyeumisasi. Tabel 5.4 dibawah ini menunjukkan pernyataan masyarakat terhadap pemilahan.

Tabel 5.5

Pernyataan Responden terhadap Pemilahan

\begin{tabular}{|c|c|c|c|}
\hline No & Pernyataan & Jumlah (orang) & Skor \\
\hline 1 & Tidak pernah & 34 & 34 \\
\hline 2 & Jarang & 28 & 56 \\
\hline 3 & Sering & 26 & 78 \\
\hline 4 & Sangat Sering & 1 & 4 \\
\hline \multirow{2}{*}{} & Jumlah & 89 & 172 \\
\cline { 2 - 4 } & Rata-rata skor & \multicolumn{2}{|c|}{$\mathbf{1 . 9 3}$} \\
\cline { 2 - 4 }
\end{tabular}

Sumber : Tabulasi Skor Hasil Jawaban Responden

Pada tabel 5.6 menunjukkan 34 orang responden menjawab tidak pernah memilah sampah, 28 orang menjawab jarang, 26 menjawab sering dan hanya 1 orang yang menjawab sangat sering. Pada tabel 5.6 diatas juga menunjukan hasil rata-rata dari pernyataan responden terhadap pemilahan sampah yakni 1.93. Dimana 1.93 tersebut masuk dalam kategori kurang baik. Kurang baik disini dapat diartikan bahwa masyarakat belum melakukan dengan baik pemilahan sampah. Padahal berdasarkan tata penerimaan sampah yang disepakati bahwa sampah diterima dalam keadaan telah dipilah. Hal ini diungkapkan oleh Kasie Sarana dan Prasarana Dinas Lingkunagn Hidup dan Pertamanan Kabupaten Klungkung.

"iyaa...awal-awalnya sampah telah dipilah oleh masyarakat. jadi pengangkutan juga ada jadwalnya. Sampah diangkut berdasarkan jenisnya. Tetapi sekarang sudah tidak lagi..”

Pernyataan Kasie Sarana dan Prasarana Dinas Lingkungan Hidup dan Pertamanan Kabupa 
ten Klungkung menguatkan bahwa masyarakat belum baik dalam memilah sampah. Yang mana sampah masing-masing orang telah dipilah dan pekerja akan mengangkut sesuai dengan jenisnya yang telah dijjadwalkan. Hanya saja fakta dilapangan mengatakan sebaliknya.

Pemilahan sampah yang tidak dilakukan oleh masyarakat kemudian dilakukan oleh pekerja TOSS. Seluruh pekerja TOSS pun menyatakan sering dan selalu melakukan pemilahan sampah sebelum memasuki proses pengolahan berikutnya. Dalam wawancara yang dilakukan, pekerja TOSS akan melakukan pemilahan sampah setelah sampah sampai di TOSS Desa Gunaksa.

"sampah yang ekonomis dipilah, baik itu botol plastik, dan plastic lain, besi dan lainnya. Lalu sampah yang bisa di cacah kita masukan ke kotak peyeum."

Pada petikan wawancara diatas memberikan penjelasan bahawa sampah akan dipilah bukan berdasarkan organik ataupun anorganik. Melainkan berdasarkan sampah yang memiliki nilai ekonomis atau tidak. Sampah yang memiliki nilai ekonomis akan dijual kembali dan yang tidak memiliki nilai ekonomis akan diolah ke tahap pengelolaan sampah berikutnya.

\section{c). Pengelolaan}

Pengelolaan merupakan tahap ketiga dari pengelolaan sampah di TOSS Desa Gunaksa. Seluruh pekerja TOSS menyatakan secara rutin dan terus menerus mengolah sampah yang masuk ke TOSS Desa Gunaksa yang berarti bahwa pengelaan sampah telah dilakukan dengan baik oleh pekrja TOSS. Hal ini pun diperkuat dari hasil wawancara salah satu perkerja TOSS.

"Iya, jadi waktu kerja kami itu 7.30 sudah harus ada di lokasi. Jam 8.00 sudah mulai kerja. Jam 10.00 istirahat dan jam 11.00 mulai kerja lagi sampai 13.00"

Dari petikan wawancara diatas menunjukkan bahwa pekerja TOSS memulai pengelolaan sampah yang masuk ke TOSS dari pukul 08.00 WITA pukul 13.00 WITA. Pekerja berkeja sesuai dengan jam kerja.
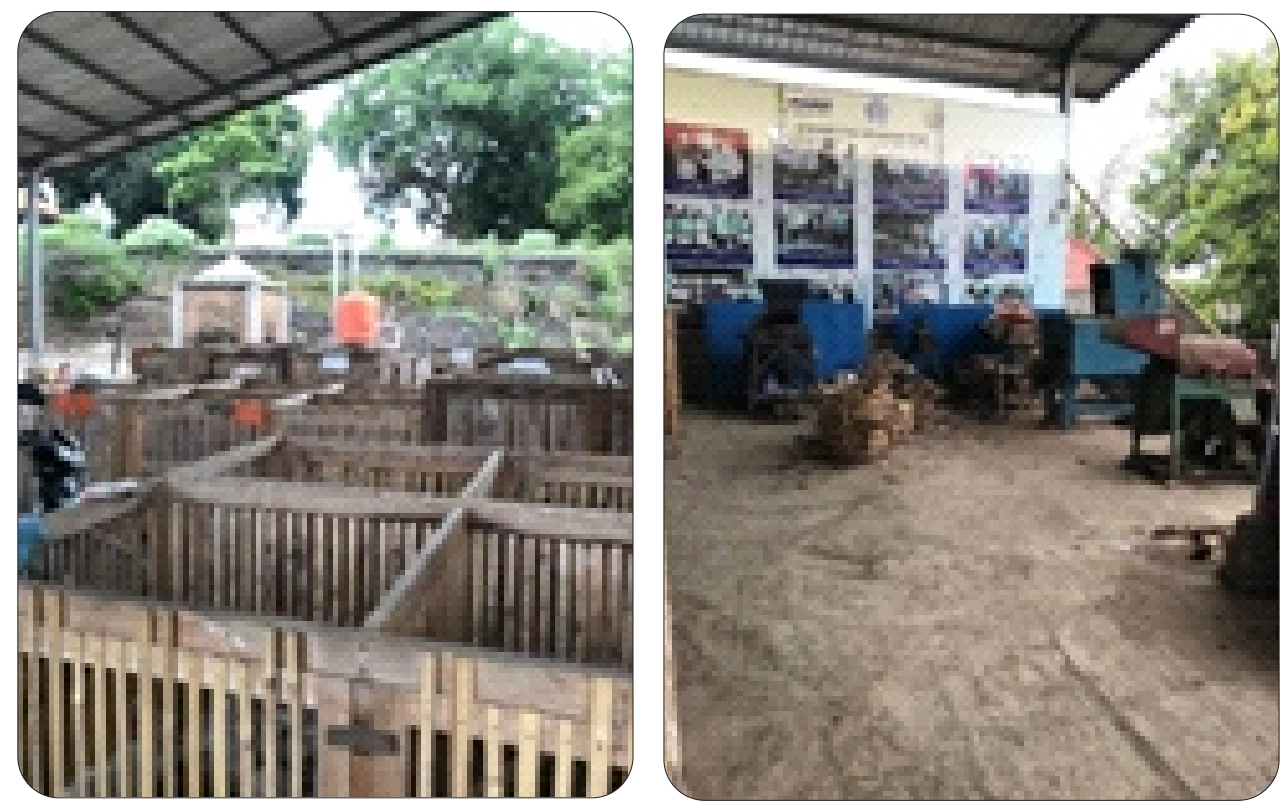

Gambar 6

Tempat Pengolahan Sampah di TOSS Desa Gunaksa 


\section{c. Output (Perubahan volume sampah, nilai ekonomis)}

\section{a). Perubahan Volume}

Adanya TOSS diharapkan dapat membantu menyelesaikan permasalah sampah di Kabupaten Klungkung. Permasalahan sampah yang paling terlihat di Kabupaten Klungkung yakni sudah tidak memadainya kapasitas TPA Sente untuk menampung sampah di Kabupaten Klungkung. Tabel dibawah ini menunjukkan hasil dari adanya TOSS terhadap perubahan volume sampah, khususnya di Desa Gunaksa.

Tabel 5.6

Pernyataan Responden terhadap Perubahan Volume Sampah

\begin{tabular}{|c|c|c|c|}
\hline No & Pernyataan & Jumlah (orang) & Skor \\
\hline 1 & Tidak berkurang & 9 & 9 \\
\hline 2 & Berkurang sedikit & 29 & 58 \\
\hline 3 & Berkurang & 34 & 102 \\
\hline 4 & Sangat berkurang & 17 & 68 \\
\hline \multirow{2}{*}{} & Jumlah & 89 & 237 \\
\cline { 2 - 4 } & Rata-rata skor & \multicolumn{2}{|c}{$\mathbf{2 . 6 6}$} \\
\cline { 2 - 4 }
\end{tabular}

Sumber : Tabulasi Skor Hasil Jawaban Responden

Tabel 5.6 menunjukkan bahwa 9 orang memberikan jawaban tidak berkurang volume sampah dengan keberadaan TOSS, 29 orang menjawab berkurang sedikit, 34 orang menjawab berkurang dan 17 orang menjawab sangat berkurang. Rata-rata skor pernyataan responden terhadap perubahan volume sampah yakni 2,66. Dimana rata-rata tersebut berada dalam kategori baik. Yang artinya terdapat perubahan volume sampah dengan adanya TOSS di Desa Gunaksa ini.

\section{b). Nilai Ekonomis}

Nilai ekonomis merupakan output lainnya selain perubahan volume sampah. Perubahan volume sampah yang telah dijabarkan pada point sebelumnya menunjukkan berada dalam kategori baik atau dengan kata lain berdampak pada perubahan volume sampah dengan adanya TOSS. Hal serupa pun terjadi pada dampak nilai ekonomis. Berikut penjabaran dapak nilai ekonomis dengan ada TOSS.

Tabel 5.7

Pernyataan Responden terhadap Dampak Ekonomis dari TOSS

\begin{tabular}{|c|c|c|c|}
\hline No & Pernyataan & Jumlah (orang) & Skor \\
\hline 1 & Tidak merasakan & 19 & 19 \\
\hline 2 & Kurang merasakan & 22 & 44 \\
\hline 3 & $\begin{array}{c}\text { Kadangkadang } \\
\text { merasakan }\end{array}$ & 20 & 60 \\
\hline 4 & Sangat merasakan & 27 & 108 \\
\hline \multirow{2}{*}{} & Jumlah & 88 & 231 \\
\cline { 2 - 4 } & Ratarataskor & \multicolumn{2}{|c|}{$\mathbf{2 . 6 3}$} \\
\hline
\end{tabular}


Pada tabel diatas dapat dilihat bahwa 19 orang todak merasakan dampak ekonomis dengan adanya TOSS. 22 orang menjawab kurang merasakan, 20 orang menjawab kadang-kadang merasakan dan 27 orang menjawab sangat merasakan. Rata-rata nilai yang didapat pada dampak ekonomi yang dirasakan yakni 2.63. Hal ini menunjukkan bahwa terdapat dampak ekonomis yang dirasakan oleh masyarakat Desa Gunaksa.

Apabila ditelisik lebih mendalam, melihat respon masyarakat terkait dampak ekonomis dengan adanya TOSS ini pada dasarnya dikembalikan kembali pada masing-masing individu atas persepsi dirinya masing-masing. Dikatakan demikian karena hasil dari pengolahan sampah TOSS Desa Gunaksa tidak serta merta dibagikan kepada masyarakat berupa uang ataupun barang. Melainkan hasil penjualan output dimasukkan dalam Badan Usaha Milik Desa (BUMDes). Hal ini pun diungkapkan oleh pekerja TOSS.

"jadi hasil pellet dari sampah ini dijual ke Indonesia Power melalui BUMDes dan hasil penjualan dikembalikan lagi ke Desa untuk di kelola"

Pada petikan wawancara diatas dapat diketahui bahwa hasil penjualan pellet yang merupaka hasil pengolahan sampah dikembalikan ke Desa untuk dikelola. Sehingga dampak ekonomis yang dirasakan oleh masing-masing individu dikembalikan sesuai dengan persepsi masyarakat makna dari dampak ekonomis.

\section{D.SIMPULAN}

Keefektifan TOSS dilihat dalam tiga bagian yakni: input, proses, dan output. Dari sisi input, hasil penelitian menunjukkan jenis sampah yang diperoleh melalui pemilahan sampah memperoleh rata-rata skor sebesar 2,28 yang artinya kurang baik, hal ini menandakan bahwa masyarakat kurang baik dalam melakukan pemilahan sampah berdasarkan jenisnya yaitu organik dan anorganik. Sedangkan sumber daya manusia yang melakukan pengolahan sampah, seluruh pekerja TOSS menyatakan bahwa jumlah pekerja TOSS sudah mencukupi dengan jumlah sampah yang harus diolah di TOSS Desa Gunaksa.

Dari sisi proses, hasil penelitian menunjukkan pengumpulan sampah oleh petugas memperoleh rata-rata skor dari semua penilaian yakni 3,22, yang berarti baik. Hal ini dapat diartikan bahwa pengangkutan sampah dari masyarakat ke TOSS Desa Gunaksa sudah berjalan dengan baik. Hal ini didukung oleh tersedianya kendaraan pengangkut sampah ke tempat pengolahan sampah TOSS Desa Gunaksa yang memadai. Pemilahan sampah yang dilakukan masyarakat menunjukkan rata-rata skor 1.93 termasuk dalam kategori kurang baik. Pengelolaan sampah yang dilakukan petugas menunjukkan bahwa seluruh pekerja TOSS menyatakan secara rutin dan terus menerus mengolah sampah yang masuk ke TOSS Desa Gunaksa. Rata-rata skor yakni 3, yang artinya bahwa pengolahan sampah telah dilakukan dengan baik oleh pekrja TOSS

Dari sisi output, perubahan volume sampah yang dihasilkan masyarakat menunjukkan ratarata skor pernyataan responden terhadap perubahan volume sampah yakni 2,66 yang berarti berada dalam kategori baik. Dengan demikian maka dapat dikatakan perubahan volume sampah semakin berkurang dengan adanya TOSS di Desa Gunaksa ini. Selain perubahan volume sampah, output juga dilihat dari nilai ekonomi. Dimana nilai ekonomis dalam penelitian ini yang menunjukkan bahwa terdapat dampak ekonomis yang semakin meningkat dirasakan oleh masyarakat Desa Gunaksa.

\section{E. DAFTAR PUSTAKA}

Chandra, Budiman, 2006. Pengantar Kesehatan Lingkungan. Jakarta: EGC 
Eisted, Rasmus and Thomas H. Christensen. 2011. Waste Management in Greenland: Goren,Sami, Feyza Ozdemir. 2010. Regulation of Waste and Waste Management in Turkey. Sage Journals.

Fathiras.2011. Analisis Pengelolaan Sampah Di Tempat Pembuangan Akhir Pasir Sembung Kabupaten Cianjur. Bogor: repository.ipb.ac.id/jspui/bitstream/123456789 /49969/3/H11nfa.pdf

Handayaningrat, Soewarno. 1994. Pengantar Studi Ilmu Administrasi dan Manajemen. Jakarta: Haji Masagung.

Kurniawan Agung. 2005. Transformasi Pelayanan Publik. Yogyakarta: Pembaruan.

Sondang P. Siagian,Kiat Meningkatkan Produktivitas kerja, Jakarta:PT Rineka Cipta,2002

Sugiyono. 2009. Metode Penelitian KuantitatifKualitatifdan R\&D. Bandung: Alfabeta

Semiawan, 2010. Metode penelitian Kualitatif. Jakarta: Grasindo

Widyatmiko, H.,Moerdjoko S. Menghindari, Mengolah dan Menyingkirkan Sampah. 2002. Yogykarta: Abdi Tandur.

Undang-Undang No 8 Tahun 2018 tentang Pengelolaan Sampah.

Dewantoro. 2009. Pengelolaan Sampah dalam http://e-journal.uajy.ac.id/3003/3/2TA12332.pdf.

Manik, Rehito Traro Hiro Karo, Indradjaja Makainas, d1l. 2015. Sistem Pengelolaan Sampah di Pulau Bunaken dalam ejournal.unsrat.ac.id

Rosidin, Imam. 2018 . 9 Rangking Kabupaten atau Kota Penghasil Sampah Tertinggi di Provinsi Bali dalam https://bali.idntimes.com/news/bali/imamrosidin/data-sampah-tertinggi-diprovinsi-bali

Subekti, Sri. 2009. Pengelolaan Sampah 3R Berbasis Masyarakat. Semarang: Jurnal Universitas Pandanaran Volume 7 Nomor 14. 